\title{
The comprehensive service system of cross-border e-commerce logistics enterprises and empirical study
}

\author{
DingQiang ${ }^{1, a}$ \\ ${ }^{1}$ Suzhou Industrial Park Institute of Services Outsourcing, Suzhou, Jiangsu, China 215123 \\ asquall.d@163.com
}

Keywords: cross-border e-commerce; multi-level demands; logistics enterprises; comprehensive service system

\begin{abstract}
It is an important strategy of China in transformation and upgrading of foreign trade to push development of cross-border e-commerce whose major support is logistics service. The paper discussed the multi-level demands of cross-border e-commerce and the current situation that our country could not adapt to the demands, established a logistics comprehensive service system which could meet multi-level demands of cross-border e-commerce, and proposed the operating modes of the service system, and based on which, the paper had an empirical study of a large-scale comprehensive logistics company. The research achievements indicated that the diversification of the current cross-border e-commerce business modes and trading categories had multi-level demands on logistic service which required logistics enterprises establish a suitable comprehensive service system, improve their service supporting capacity and strengthen their overall comprehensive competitiveness.
\end{abstract}

\section{Introduction}

In recent years, cross-border e-commerce has been keeping a rapid increase while traditional foreign trade developed slowly. The all-dimensional development of cross-border e-commerce improved its demands on service function, service level and service cost of logistics, and the demands were more and more hierarchical. It is of great importance to promote development of cross-border e-commerce and improve comprehensive competitiveness of logistics enterprises.

\section{Evaluation model of cross-border e-commerce logistics enterprises based on the method of fuzzy comprehensive evaluation}

1. Establish a factor set $U$ for service quality evaluation of cross-border e-commerce

For the construction of a service quality evaluation index system for cross-border e-commerce, factors that have an impact on comprehensive assessment of the enterprises could be gathered to form a set named factor set (as shown in table 1) which can be defined as $U=(\mathrm{U} 1, \mathrm{U} 2, \mathrm{U} 3, \mathrm{U} 4)$. And here it can be interpreted as $\mathrm{U}=$ (cooperative partner, overseas warehouse, level of information, mode of transformation)

Table 1 Comprehensive evaluation indexes of cross-border logistics enterprises

\begin{tabular}{|c|l|}
\hline First-level indexes & \multicolumn{1}{|c|}{ Second-level indexes } \\
\hline \multirow{4}{*}{ Cooperative partner U1 } & Business balance between cooperative partners U11 \\
\cline { 2 - 2 } & Service quality (time, price and so on) of cooperative partners U12 \\
\cline { 2 - 2 } & Logistics service coverage of cooperative partners U13 \\
\hline \multirow{4}{*}{ Overseas warehouse U2 } & Local customs clearance ability of cooperative partners U14 \\
\cline { 2 - 2 } & Ownership of overseas warehouses U21 \\
\cline { 2 - 2 } & Possibility of overseas warehouses in providing localized services U22 \\
\cline { 2 - 2 } $\begin{array}{c}\text { Level of information } \\
\text { U3 }\end{array}$ & Product categories of overseas warehouses U23 \\
\cline { 2 - 2 } & Logistics management information system U31 \\
\cline { 2 - 2 } & Customs clearance information level U32 \\
\hline \multirow{2}{*}{$\begin{array}{c}\text { Transformation } \\
\text { provider U4 }\end{array}$} & Mobile information client U33 \\
\cline { 2 - 2 } & Airline U41 \\
\cline { 2 - 2 } & Airline \& land transportation U42 \\
\hline
\end{tabular}


2. Establish a grade field V for evaluation of cross-border e-commerce logistics enterprises

The grade field $\mathrm{V}$ of evaluation of cross-border e-commerce logistics enterprises is $\mathrm{V}=(\mathrm{v} 1, \mathrm{~V} 2, \ldots, \mathrm{vn})$, with $\mathrm{Vj}$ referring to evaluation standards and $\mathrm{j}=1,2, \ldots, \mathrm{n}$. The purpose of the fuzzy comprehensive evaluation is to select an optimum evaluation result by taking many influencing factors into consideration. The evaluation can be generally divided into 3 to 5 grades. And according to the actual situation, the study set up 4 evaluation grades, that is to say, $\mathrm{V}=(\mathrm{V} 1, \mathrm{~V} 2, \mathrm{~V} 3, \mathrm{~V} 4)$, or $\mathrm{V}=$ (very good, good, ordinary, worse) in a more detailed way.

3. Determine weight vectors AHP of various evaluation factors

To indicate the importance degree of the factors, the weight set $\mathrm{A}$ of the first-level indictors can be defined as $\mathrm{A}=(\mathrm{A} 1, \mathrm{~A} 2, \mathrm{~A} 3, \mathrm{~A} 4)$. Ai is the weight of the factor $\mathrm{I}$, which conforms to $0<\mathrm{A} i$, and $\sum \mathrm{A} i=1$. Each influencing factor $U i j$ should be given a weight. The weight set $A i, A_{i}=\left(a_{i 1}, a_{i 2}, \ldots, a_{\text {in }}\right)$, is fuzzy factors of weight allocation, and $\mathrm{a}_{\mathrm{ij}}$ is the weight of the factor $\mathrm{ij}$. Weight can be determined through two methods: one is to judge according to subjective experience; and the other is to measure with statistic methods such as analytic hierarchy process.

4. Evaluate each factor. To determine the comprehensive assessment of the fuzzy relation matrix $\mathrm{R}, \mathrm{N}$ experts from the cross-border e-commerce logistics industry were invited to form a evaluation team and assess every factor of the factor set $\mathrm{U}$.

Table 2 Scoring evaluation table of experts

\begin{tabular}{|c|c|c|c|c|}
\hline \multirow{2}{*}{ Factors } & \multicolumn{4}{|c|}{ Remark } \\
\cline { 2 - 5 } & $\mathrm{v} 1$ & $\mathrm{v} 2$ & $\mathrm{v} 3$ & $\mathrm{v} 4$ \\
\hline $\mathrm{Ui} 1$ & $\mathrm{Xi1} 1^{(\mathrm{k})}$ & $\mathrm{Xi12}{ }^{(\mathrm{k})}$ & $\mathrm{Xi13}{ }^{(\mathrm{k})}$ & $\mathrm{Xi14}$ \\
\hline $\mathrm{L}$ & $\mathrm{L}$ & $\mathrm{L}$ & $\mathrm{L}$ & $\mathrm{L}$ \\
\hline $\mathrm{U}_{\text {in }}$ & $\mathrm{X}_{\text {in } 1}{ }^{(\mathrm{k})}$ & $\mathrm{X}_{\text {in2 }}{ }^{(\mathrm{k})}$ & $\mathrm{X}_{\text {in } 3}{ }^{(\mathrm{k})}$ & $\mathrm{X}_{\text {in }}{ }^{(\mathrm{k})}$ \\
\hline
\end{tabular}

In the above scoring table, $\mathrm{x}_{\mathrm{ijl}}(\mathrm{k})$ is the membership degree of the first remark $\mathrm{V}_{\mathrm{l}}$ by expert $\mathrm{K}$ according to the factor $\mathrm{U}_{\mathrm{li}}$. The overall membership degree $\gamma_{\mathrm{ijl}}$ can be seen in the following formula:

$$
r_{y l}=\frac{\sum_{k=1}^{k-N} x_{i{ }^{(a)}}}{100 N}
$$

And the fuzzy evaluation matrix can be obtained:

$$
\mathrm{R}=\left(\gamma_{\mathrm{ijl}}\right)=\left(\begin{array}{cccc}
\gamma_{\mathrm{i} 11} & \gamma_{\mathrm{i} 12} & \gamma_{\mathrm{i} 13} & \gamma_{\mathrm{i} 14} \\
\gamma_{\mathrm{i} 21} & \gamma_{\mathrm{i} 22} & \gamma_{\mathrm{i} 23} & \gamma_{\mathrm{i} 24} \\
& & & \\
\cdots & \ldots & \cdots & \cdots \\
\gamma_{\mathrm{in} 1} & \gamma_{\mathrm{in} 2} & \gamma_{\mathrm{in} 3} & \gamma_{\mathrm{in} 4}
\end{array}\right), \gamma_{\mathrm{ijl}} \in_{[0,1]}
$$

$\gamma_{\mathrm{ijl}}$ is the membership degree of the first remark $\mathrm{V}_{\mathrm{l}}$ according to the factor Uij. The normalization process: $\sum \mathrm{r}_{\mathrm{ijl}}=1$

\section{Fuzzy comprehensive evaluation}

By assessing $\mathrm{n}$ factors of $\mathrm{Ui}$, the evaluation matrix Ri of single factors is formed. Using weighted average $\mathrm{M}(.,+)$ operator to combine $\mathrm{Ri}$ and weight vector $\mathrm{Ai}$ in a vague way, the evaluation results $\mathrm{Bi}$ of factor set $\mathrm{Ui}$ can be acquired, and $\mathrm{Bi}=\mathrm{Ai} * \mathrm{Ri}=\left(\mathrm{b}_{\mathrm{i} 1}, \mathrm{~b}_{\mathrm{i} 2}, \mathrm{~b}_{\mathrm{i} 3}, \mathrm{~b}_{\mathrm{i} 4}\right)$. With the help of B1,B2,B3 and B4, the evaluation matrix $U$ of single factors can be realized, and $U=（ U 1, U 2, U 3, U 4 ）$ :

$\mathrm{R}=\begin{array}{r}\mathrm{B} 2 \\ \mathrm{~B} 3 \\ \mathrm{~B} 4\end{array}=\left(\begin{array}{llll}\mathrm{b}_{11} & \square \mathrm{b}_{12} & \mathrm{~b}_{13} & \mathrm{~b}_{14} \\ \mathrm{~b}_{21} & \mathrm{~b}_{22} & \mathrm{~b}_{23} & \mathrm{~b}_{24} \\ \mathrm{~b}_{31} & \mathrm{~b}_{32} & \mathrm{~b}_{33} & \mathrm{~b}_{34} \\ \mathrm{~b}_{41} & \mathrm{~b}_{42} & \mathrm{~b}_{43} & \mathrm{~b}_{44}\end{array}\right)$

$b_{i j}$ is the membership degree of the evaltation objects to the factor vj of the fuzzy subset of evaluation grade.

\section{Multi-level demands of Chinese cross-border e-commerce on logistics service}

1. General situation of the development of Chinese cross-border e-commerce

The development of cross-border e-commerce is a significant strategy of China in transformation 
and upgrading of foreign trade, a new engine to realize the transmission from a large trading nation to a powerful one, and a new type trading mode. It mainly depends on internet to realize the cooperation with cross-border logistics and meet customer demands. Cross-border e-commerce has many merits, including low threshold, fewer links, low cost and short cycle, and it has developed very fast in the whole world. Cross-border e-commerce of China will keep the rapid increase and become the biggest e-commerce market of the world.

Chinese cross-border e-commerce proposed multi-level demands on logistics service and has witnessed a continuous and rapid increase. With the all-dimensional development, it increased its demands on service function, service level and service cost and the demands were more and more hierarchical. The one is multi-level demands, and the other is the multi-level demands of Chinese cross-border e-commerce on logistics service, which was shown in table 3. Business modes of Chinese cross-border e-commerce were diversified, thus a corresponding comprehensive service system should be established to provide a sound logistics support for cross-border e-commerce.

Table 3 Multi-level demands of Chinese cross-border e-commerce on logistics service

\begin{tabular}{|c|c|c|c|c|c|c|c|}
\hline \multirow{2}{*}{$\begin{array}{l}\text { Categories } \\
\text { of } \\
\text { cross-border } \\
\text { e-commerce }\end{array}$} & \multirow{2}{*}{$\begin{array}{l}\text { Categories of } \\
\text { cross-border } \\
\text { e-commerce }\end{array}$} & \multirow{2}{*}{$\begin{array}{c}\text { Business } \\
\text { modes of } \\
\text { cross-border } \\
\text { e-commerce }\end{array}$} & \multirow[b]{2}{*}{$\begin{array}{c}\text { Characteristics } \\
\text { of orders }\end{array}$} & \multicolumn{3}{|c|}{ Demands on logistics service } & \multirow{2}{*}{$\begin{array}{c}\text { Operatin } \\
\text { g modes } \\
\text { of } \\
\text { logistics }\end{array}$} \\
\hline & & & & Time & $\begin{array}{l}\text { Economical } \\
\text { efficiency }\end{array}$ & safety & \\
\hline $\begin{array}{c}\text { Economical } \\
\text { international } \\
\text { normal post }\end{array}$ & $\begin{array}{l}\text { Middle and } \\
\text { low price } \\
\text { goods }\end{array}$ & $\mathrm{B} 2 \mathrm{C} / \mathrm{C} 2 \mathrm{C}$ & $\begin{array}{l}\text { Moderate value } \\
\text { and batch; low } \\
\text { demands on } \\
\text { freight bear } \\
\text { ability and } \\
\text { delivery time; } \\
\text { intermediate } \\
\text { market demand }\end{array}$ & 6-15 days & $\begin{array}{l}\text { Low freight } \\
\text { price nearly } \\
\text { equal to delivery } \\
\text { price of } \\
\text { international } \\
\text { parcel, and } \\
\text { varying for } \\
\text { different } \\
\text { destinations }\end{array}$ & $\begin{array}{c}\text { Stable } \\
\text { safety; low } \\
\text { cargo } \\
\text { damage; } \\
\text { alterative } \\
\text { price } \\
\text { insurance } \\
\text { service and } \\
\text { specialized } \\
\text { insurance } \\
\text { agency } \\
\text { service } \\
\end{array}$ & $\mathrm{N}-1-\mathrm{N}$ \\
\hline $\begin{array}{l}\text { High-end } \\
\text { international } \\
\text { air express }\end{array}$ & $\begin{array}{l}\text { Luxuries of } \\
\text { high price }\end{array}$ & B2C & $\begin{array}{l}\text { High value; } \\
\text { strong freight } \\
\text { bear ability; } \\
\text { light and small; } \\
\text { safe, reliable } \\
\text { and rapid in } \\
\text { delivery; } \\
\text { unstable market } \\
\text { demand }\end{array}$ & 2-5 days & $\begin{array}{l}\text { Price can be } \\
\text { higher than the } \\
\text { one mentioned } \\
\text { above to some } \\
\text { extent, but } \\
\text { should adapt to } \\
\text { cross-border } \\
\text { e-commerce } \\
\text { demands and } \\
\text { have a } \\
\text { sustainable } \\
\text { competitiveness } \\
\text {. }\end{array}$ & $\begin{array}{c}\text { High } \\
\text { safety; } \\
\text { seldom } \\
\text { cargo } \\
\text { damage; } \\
\text { alterative } \\
\text { price } \\
\text { insurance } \\
\text { service and } \\
\text { specialized } \\
\text { insurance } \\
\text { agency } \\
\text { service }\end{array}$ & $\mathrm{N}-\mathrm{N}-\mathrm{N}$ \\
\hline $\begin{array}{l}\text { Compound } \\
\text { international } \\
\text { cargo } \\
\text { storage }\end{array}$ & $\begin{array}{l}\text { Standardized } \\
\text { necessaries }\end{array}$ & B2B2C & $\begin{array}{l}\text { Large batch; } \\
\text { low demands on } \\
\text { freight bear } \\
\text { ability and } \\
\text { delivery time; } \\
\text { stable and } \\
\text { predictable } \\
\text { market demand }\end{array}$ & $\begin{array}{c}\text { 11-20 days } \\
\text { (transporting } \\
\text { period) }\end{array}$ & $\begin{array}{l}\text { Freight price } \\
\text { matches volume } \\
\text { closely and keep } \\
\text { a minimum } \\
\text { freight price }\end{array}$ & $\begin{array}{c}\text { Basic } \\
\text { guarantee } \\
\text { for safety } \\
\text { and } \\
\text { damage } \\
\text { compensat } \\
\text { ion; } \\
\text { alterative } \\
\text { specialized } \\
\text { insurance } \\
\text { agency } \\
\text { service } \\
\end{array}$ & $1-1-\mathrm{N}$ \\
\hline $\begin{array}{l}\text { Customized } \\
\text { international } \\
\text { supply chain } \\
\text { service }\end{array}$ & $\begin{array}{c}\text { Special } \\
\text { products }\end{array}$ & $\begin{array}{c}\text { Chain } \\
\text { management }\end{array}$ & $\begin{array}{l}\text { Any category of } \\
\text { the above three } \\
\text { with products of } \\
\text { high price as } \\
\text { major ones }\end{array}$ & $\begin{array}{r}\text { Raw materi } \\
\text { storage and s } \\
\text { internation } \\
\text { changing and } \\
\text { sound servic }\end{array}$ & $\begin{array}{l}\text { purchasing and ma } \\
\text { ck control of finish } \\
\text { transport and order } \\
\text { funding beyond the } \\
\text { chain and reasonab } \\
\text { goal }\end{array}$ & $\begin{array}{l}\text { lagement; } \\
\text { d products; } \\
\text { shipping; } \\
\text { borders with } \\
\text { cost as its }\end{array}$ & SCM \\
\hline
\end{tabular}




\section{Construction of a comprehensive service system of logistics enterprises to adapt to multi-level demands of cross-border e-commerce}

To adapt to multi-level demands of cross-border e-commerce on logistics, improve service ability of logistics enterprises to cross-border e-commerce and reduce logistics cost of cross-border e-commerce, logistics enterprises should actively explore a comprehensive service system for cross-border e-commerce and drive the sustainable development with service innovation by enhancing scale operation. First, they should improve the scale and intensification of logistics enterprises to establish a comprehensive service system. Second, they must adapt to multi-level demands of cross-border e-commerce. Third, they should optimize their operating modes of the comprehensive service system.

\section{Case empirical research}

Cross-border e-commerce is a new engine to drive logistics business increase. And it drives a new fierce competition in the logistics industry with an interactive struggle of "demand upgrading service upgrading - competition upgrading" carried out between cross-border e-commerce companies and logistics enterprises, and among logistics enterprises.

(1) Investigate customer evaluation and figure out data of service shortcomings. As for cross-border e-commerce customers, the ABC Company carried out questionnaire surveys about the logistics service system at regular intervals so as to understand their evaluation to significance and performance of each index of each service. Taking the cross-border e-commerce international air express service of the ABC Company as an example, the average results of customer evaluation about service significance and performance in 2016 were shown in table 4 . Table 4 showed that the index E1, competitiveness of freight price, in the whole industry was only 1.96, and index E2, rationality of freight price structure and compute mode which conforms to the development of the industry, was 1.83, which fully indicated that cross-border e-commerce customers expecting the ABC Company to adjust the price level and structure of international express delivery. In addition, the index H5 was only 1.87.

(2) Focus on "first priority for improvement" fields and optimize the freight price system. According to table 4, by locating the 4 dimensions and 15 major service indexes, an evaluation coordinate graph could be obtained and it was shown in figure 1. Indexes within the quadrant "of great importance - performance below average" belonged to "first priority for improvement" fields. The two indexes of the ABC Company in the dimension "economical efficiency" of express delivery were both listed in, but the index H5 was not, which indicated that the company should be focused on "economical efficiency" and optimize the freight prices system.

(3) Low logistics cost and further improvement of service competitiveness. After the optimization of the freight price system, the average score of index E1, the competitiveness of the general freight price level in the industry, increased from 1.96 to 3.12, and the index E2, rationality of freight price structure and compute mode which conforms to the development of the industry, increased from 1.83 to 3.23. The evaluation of clients about the two indexes both exceeded 3 , entering the quadrant of maintenance. By adjusting the freight price system timely, the ABC Company has improved the overall competitiveness of express service. 
Table 4 customer evaluation results about international air express service of the ABC Company in 2016

\begin{tabular}{|c|c|c|c|c|}
\hline Dimensions & \multicolumn{2}{|c|}{$\begin{array}{l}\text { Major quality evaluation indexes of cross-border international air express } \\
\text { service }\end{array}$} & $\begin{array}{l}\text { Average } \\
\text { value of } \\
\text { significance } \\
\text { evaluation }\end{array}$ & $\begin{array}{l}\text { Average } \\
\text { value of } \\
\text { performanc } \\
\text { e evaluation }\end{array}$ \\
\hline \multirow{5}{*}{ Time } & H1 & $\begin{array}{l}\text { Delivery from addresser to recipients within a promised time or } \\
\text { a time expected by customers (delay because of special factors } \\
\text { like force majeure is excluded). No or very few negative } \\
\text { comments }\end{array}$ & 3.83 & 3.93 \\
\hline & $\mathrm{H} 2$ & $\begin{array}{l}\text { House call or cross-border e-commerce goods delivery within in } \\
\text { a time scheduled or appointed }\end{array}$ & 3.76 & 3.89 \\
\hline & H3 & $\begin{array}{l}\text { Reply service consultation of e-commerce customers at home } \\
\text { and abroad timely or react to various service demands rapidly }\end{array}$ & 3.16 & 3.11 \\
\hline & $\mathrm{H} 4$ & $\begin{array}{l}\text { Provide rapid and various approaches (cross-board e-commerce } \\
\text { websites, WeChat, text message, telephone and so on) to help } \\
\text { customers at home and aboard to inquire detailed information of } \\
\text { transportation and receiving flexibly and conveniently. }\end{array}$ & 2.98 & 3.66 \\
\hline & H5 & $\begin{array}{l}\text { Service site setting, express delivery and receiving, and business } \\
\text { hours must be arranged well to serve cross-border e-commerce } \\
\text { clients effectively. }\end{array}$ & 1.25 & 1.87 \\
\hline \multirow{3}{*}{ safety } & $\mathrm{S} 1$ & $\begin{array}{l}\text { No or very few accidents like damage, lackage or loss. The low } \\
\text { accident rate is in an international leading position. Provide } \\
\text { alternative specialized insurance service and price insurance } \\
\text { service }\end{array}$ & 3.97 & 3.91 \\
\hline & $\mathrm{S} 2$ & $\begin{array}{l}\text { Apply specialized packaing and tools for transportation and } \\
\text { handling; be equipped with advanced transport vehicles and } \\
\text { processing equipments }\end{array}$ & 1.96 & 3.88 \\
\hline & S3 & $\begin{array}{l}\text { Do not disclose or embezzle relevant information of addressers } \\
\text { and items (situations that information disclosure are requied by } \\
\text { customs or public security officers are excluded) }\end{array}$ & 3.89 & 3.65 \\
\hline \multirow{5}{*}{ Reliability } & $\mathrm{R} 1$ & $\begin{array}{l}\text { International express cover the whole world, making it } \\
\text { convenient to carry out cross-border e-commerce business with } \\
\text { most countries and regions }\end{array}$ & 2.84 & 3.99 \\
\hline & $\mathrm{R} 2$ & $\begin{array}{l}\text { Service staff assist addressers write and print correctly, or use an } \\
\text { information system }\end{array}$ & 1.89 & 3.05 \\
\hline & R3 & $\begin{array}{l}\text { Service staff guide recipients check items and sign correctly on } \\
\text { the spot, and process demands for changing and refunding } \\
\text { patiently }\end{array}$ & 2.12 & 3.23 \\
\hline & R4 & $\begin{array}{l}\text { Service staff must be kind and polite to customers, and abide by } \\
\text { the idea of customer first }\end{array}$ & 2.86 & 3.12 \\
\hline & R5 & $\begin{array}{l}\text { Service staff must have a positive image, and wear clothes with } \\
\text { corporate identify or work cards }\end{array}$ & 1.87 & 3.56 \\
\hline \multirow{2}{*}{$\begin{array}{l}\text { Economical } \\
\text { efficiency }\end{array}$} & E1 & $\begin{array}{l}\text { The general freight price level has competitiveness in the } \\
\text { industry }\end{array}$ & 3.91 & 1.96 \\
\hline & E2 & $\begin{array}{l}\text { Reasonable freight price and compute modes, conforming to the } \\
\text { development of the industry }\end{array}$ & 3.52 & 1.83 \\
\hline
\end{tabular}

\section{Of great importance}

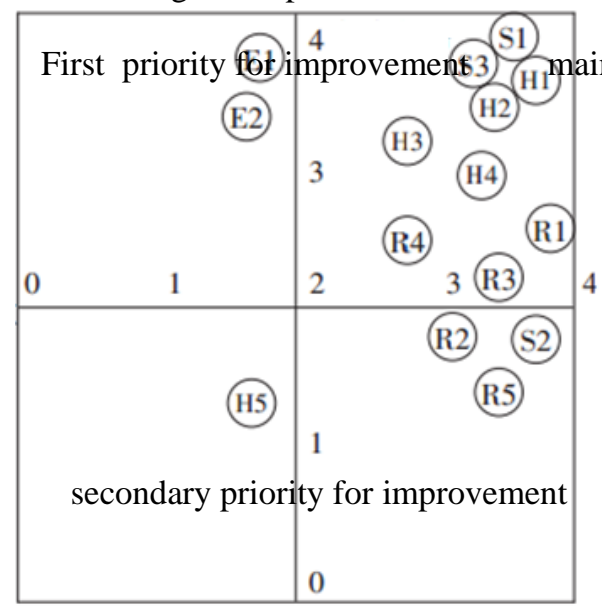

Of little importance

performance below the average

\section{Of itle inportance}

Figure 1 Evaluation about international air express service of the ABC Company in 2016 


\section{Conclusion}

The study established a logistics enterprise comprehensive service system to adapt to multi-level demands of cross-border ecommerce and put forward the operating modes of the comprehensive service system. The diversification of the current cross-border e-commerce business modes and trading categories had multi-level demands on logistic service, which required logistics enterprises establish corresponding comprehensive service systems since a comprehensive service system that could adapt to multi-level demands of cross-border e-commerce could improve their service supporting capacity and reduce logistics cost for cross-border e-commerce effectively.

\section{References}

[1] Li Xudong, Wang Yaoqiu. Service function Integration and optimization of cross-border logistics enterprises under the cross-border e-commerce multi-dimensional mode [J]. Commercial business research, 2016,05:78-80

[2] Jiao Chaoxia. Strategy study on cross-border e-commerce development of foreign trade enterprises of Liaoning Province [J]. Journal of Liaoning University of Technology (social sciences), 2016,02:21-23

[3] Yang Xujie. The dilemma and suggestions of Chinese cross-border e-commerce in logistics [J]. Business Theory of China, 2016,08:132-133.

[4] Qi Weiwei. Study on logistics modes of cross-border e-commerce enterprises—taking Qingdao as an example [J]. Management of medium and small-sized enterprises and technology (published every top 10 days), 2016,05:11-12.

[5] Yan Luxin. Problems and strategies of cross-border e-commerce logistics of Heilongjiang [J]. Business economy, 2016,04:11-12+85. 